\title{
LASKAMI SEYNĄCY \\ WIZERUNEK CHRYSTUSA NIOSĄCEGO KRZYŻ Z KOŚCIOLA KARMELITÓW BOSYCH WE LWOWIE. Z BADAŃ NAD RECEPCJĄ GRAFIKI W MALARSTWIE POLSKIM XVII W.
}

W krakowskim kościele karmelitów trzewiczkowych Na Piasku, w dolnej partii retabulum ołtarza ustawionego w pierwszej kaplicy od prezbiterium, po stronie południowej ${ }^{1}$, umieszczony jest wizerunek Chrystusa niosącego krzyż (il. 1). Obraz, namalowany w XVII w., przywieziony został po drugiej wojnie światowej ze Lwowa; pierwotnie znajdował się w kościele karmelitów bosych pw. św. Michała Archanioła na przedmieściu Halickim za murami miasta, w ołtarzu w przylegającej do prezbiterium kaplicy Chrystusa Miłosiernego ${ }^{2}$. Ów wizerunek - znany jako Jezus pociecha utrapionych ${ }^{3}$ - otoczony był przez wiernych kultem, a o doznanych łaskach świadczą liczne wota przymocowane do wyściełanego aksamitem tła ${ }^{4}$.

Chrystus przedstawiony został w półpostaci (ściślej - w ujęciu do bioder), z glową lekko pochyloną pod ciężarem dźwiganego krzyża, podtrzymywanego oburącz - prawa ręka uniesiona ku górze i lekko ugięta w łokciu podpiera po-

\footnotetext{
${ }^{1}$ Oltarz, wykonany w 3 ćw. XVIII w. (zapewne w końcu lat sześćdziesiąych lub siedemdziesiątych tegoż stulecia) dedykowany jest obecnie św. Antoniemu, pierwotnie nosił wezwanie śś. Piotra i Pawła - zob. A. D e $t$ l of $\mathrm{f}$, Zespót osiemnastowiecznych oltarzy bocznych w kościele karmelitów na Piasku w Krakowie - próba określenia stanu pierwotnego i kwestia autorstwa, Rocznik Krakowski, t. LXIX, 2003, s. 128-129, il. 10.

${ }^{2}$ O. B. J. W a n a OCD, Zakon karmelitów bosych w Polsce. Klasztory karmelitów i karmelitanek bosych 1605-1675, Kraków 1979, s. 183. Wzmianki o obrazie podają też m.in. M. R o ż e k, Kościót oo. Karmelitów Na Piasku w Krakowie. Przewodnik dla zwiedzajacych, Kraków 1990, s. 14, il. 7; R. K a c zorow sk i, Zabytki starego Lwowa, Warszawa 1990, s. 113; R. Ró g, Karmelici. Duch, historia, kultura, Kraków 1997, s. 46, il. na s. 43. Po kasacie lwowskiego zgromadzenia karmelitów bosych opuszczony klasztor objęli na krótko oo. reformaci; od 1789 r. aż do 1945 r. klasztor pozostawał w posiadaniu karmelitów trzewiczkowych, którzy przewieźli niektóre cenne przedmioty - w tym omawiany obraz - do swej krakowskiej siedziby.

${ }^{3}$ Takie określenie użyte zostało m.in. na miedziorycie wykonanym w 2 poł. XVIII wieku przez Teodora Rakowieckiego - zob o. B. J. W a n a OCD, dz.cyt., il. 17.

${ }^{4}$ Obecnie zawieszone są wota w kształcie gorejącego serca $i$ wotum $w$ formie ręki; dawniej jak świadczy fotografia obrazu wykonana przed 1990 r. przymocowane też były innego rodzaju wota, a także ryngrafy (por. M. Rożek, dz. cyt., il. 7).
} 
ziomą belkę, dociśniętą do barku ręką lewą. Skierowane ku górze spojrzenie, jakby podpuchnięte powieki, zmarszczki i cienie rysujące się pod oczami, usta zaciśnięte w grymasie cierpienia sugestywnie oddają malujące się na twarzy Zbawiciela zmęczenie, ból i smutek. Na postać dźwigającego krzyż Chrystusa nałożona jest sukienka (nie osłonięta jest tylko twarz) - szata z długimi rękawami, ozdobiona niewielkimi, podobnymi do stokrotek kwiatkami, z drobnymi, równolegle układającymi się fałdami, korona cierniowa na głowie Jezusa i okładzina krzyża wykonane zostały ze srebrnej, trybowanej blachy.

Obecność sukienki ${ }^{5}$ utrudnia ocenę poziomu artystycznego omawianego obrazu; można jednak stwierdzić poprawny modelunek pełnej wyrazu twarzy Chrystusa, zwraca też uwagę specyficzny sposób podtrzymywania krzyża, wyróżniająey nasz wizerunek spośród wielu innych realizacji tego popularnego w sztuce tematu. Jednak w tym samym kościele karmelitów trzewiczkowych $\mathrm{Na}$ Piasku, w kaplicy Matki Boskiej Szkaplerznej, znajduje się feretron z obrazem, przedstawiającym tak samo upozowanego Chrystusa, namalowanym w $1786 \mathrm{r}$. przez krakowskiego malarza Kazimierza Mołodzińskiego ${ }^{6}$, co pozwala domyślać się istnienia wspólnego pierwowzoru. Jest nim miedzioryt wykonany przez Raphaela Sadelera I na podstawie kompozycji Petera de Witte zwanego Candidem? (i1. 2).

Osobowość artystyczna Petera de Witte - urodzonego około $1548 \mathrm{r}$. w Brugii malarza, rysownika i sztycharza - kształtowała się pod wpływem sztuki włoskiej, bowiem już w dzieciństwie opuścił on rodzinne miasto i wraz z ojcem zamieszkał we Florencji; po wyjeździe z Włoch w 1586 r. osiadł w Monachium, gdzie zmarł w $1628 \mathrm{r}$. W latach $1593-1597$ i od $1604 \mathrm{r}$, aż do śmierci w 1632 r. przebywał też w Monachium wykonawca ryciny, przedstawiciel słynnej, wywodzącej się z Antwerpii rodziny sztycharzy i wydawców - Raphael Sadeler I. Można więc przypuszczać, że miedzioryt z Chrystusem niosącym krzyż wykonany był w okresie, gdy obaj artyści pracowali w Monachium, a więc nie wcześniej niż w 1593 r.; terminus ad quem wyznacza data śmierci rytownika $1632 \mathrm{r}$.

Porównując obraz z ryciną dostrzegamy pewne różnice. I tak, malarz przedstawil Chrystusa w ujęciu do bioder, a nie, jak na pierwowzorze do pasa, nieco inaczej ułożył prawą dłoń, a także wprowadził niewielkie zmiany w wyglądzie twarzy Zbawiciela, który nie spogląda w naszą stronę, lecz kieruje wzork ku górze.

Łaskami słynący wizerunek Chrystusa niosącego krzyż z lwowskiego kościoła karmelitów bosych okazal się więc być jednym z bardzo wielu obrazów

${ }^{5}$ Zwyczaj ozdabiania sukienkami obrazów cieszących się kultem szeroko omawia $\mathrm{M}$. Karpow ic z, Uwagi o aplikacjach na obrazy i roli srebra $w$ dawnej Rzeczypospolitej, „Rocznik Historii Sztuki” t. XVI, 1987, s. 123-156.

${ }^{6}$ O. P. S p ill e r OCarm, G. Z a ń-Og r a b e k, Arcybractwo Szkaplerza Świętego przy Kościele Karmelitów w Krakowie Na Piasku. Historia, duchowość, ikonografia, Kraków 2001, il. 67.

${ }_{7}^{7}$ F.W. H. Holls te in, Dutch and Flemish Etchings, Engravings and Woodcuts 1450 -1700 , t. XXI-XXII, Amsterdam 1980, nr 48. 
wykonanych w oparciu o wzór graficzny; wśród nich są wizerunki również cieszące się kultem, takie jak m.in. obrazy:

- Matki Boskiej Ostrobramskiej ${ }^{8}$,

- Matki Boskiej Miłosierdzia w Piekoszowie ${ }^{9}$,

- Matki Boskiej Kalwaryjskiej w Kalwarii Pacławskiej ${ }^{10}$ i

- Matki Boskiej Bolesnej w Chełmnie Pomorskim ${ }^{1 !}$.

\section{Miraculous Image of Christ Carrying Crucifix in Discalced Carmelites Church in Lviv. \\ From Studies on Reception of Graphic Art in Polish Painting of $17^{\text {th }}$ Century Summary}

In one of the side altars in the Cracow church of the Calced Carmelites 'Na Piasku' there is a miraculous image of Christ carrying a crucifix, brought after World War II from the Discalced Carmelites church in Lviv. The painting is one of the many examples of using graphic models by painters as it was painted from a drawing made according to a composition of Peter de Witte, called Candid (born ca 1548 in Bruges, died in 1628 in Munich) by Raphael Sadeler I (born 1561 in Antwerp, died 1632 in Prague).

${ }^{8} \mathrm{Na}$ temat posłużenia się grafiką przez twórcę obrazu Matki Boskiej Ostrobramskiej zob. M. K a ł a m a j s k a - S a e e d, Geneza artystyczna obrazu Matki Boskiej Ostrobramskiej, „Folia Historiae Artium" t. XXVI, 1990, s. 78-80, ryc. 9-12.

${ }_{9}$ Wzór graficzny obrazu - rycinę wykonaną według Pierre'a Mignarda - wskazał M. $\mathrm{K}$ a le c ińs $\mathrm{k}$ i, Wzory malarstwa seicenta w Malopolsce i na Rusi w XVII $i$ XVIII w. Z problematyki recepcji wzorów wloskich $w$ malarstwie barokowym w Polsce [w:] tegoż, Muta praedicatio. Studia z historii i recepcji malarstwa wtoskiego doby potrydenckiej, Warszawa 1999, s. 99 , il. $92-93$.

${ }^{10}$ Obraz (reprodukcja - zob. Z dawna Polski Tyś Królowa, Koronowane wizerunki Matki Bozej 1717-1996. Przewodnik po sanktuariach maryjnych, wydanie poprawione i uzupetnione, Niepokalanów 1996, nr 24) wiernie powtarza rycinę wykonaną w 1595 r. przez Jana Sadelera I (reprodukcja ryciny - The Illustrated Bartsch, t. 70, supplement, part 2, New York 2001, nr 249).

" Obraz (reprodukcja - zob. Z dawna Polski Tyś Królowa dz. cyt., nr 8) wzorowany jest na rycinie wykonanej w 1585 r. przez Hieronima Wierixa według kompozycji Martena de Vosa (reprodukcja ryciny - zob. M. Mauquoy-Hendrickx, Les estampes des Wierix conservées au Cabinet des estampes de la Bibliotheque Royale Albert I ${ }^{\text {cr }}$. Cataloque raisonné, t. 1, Bruxelles 1978 , nr 786). 


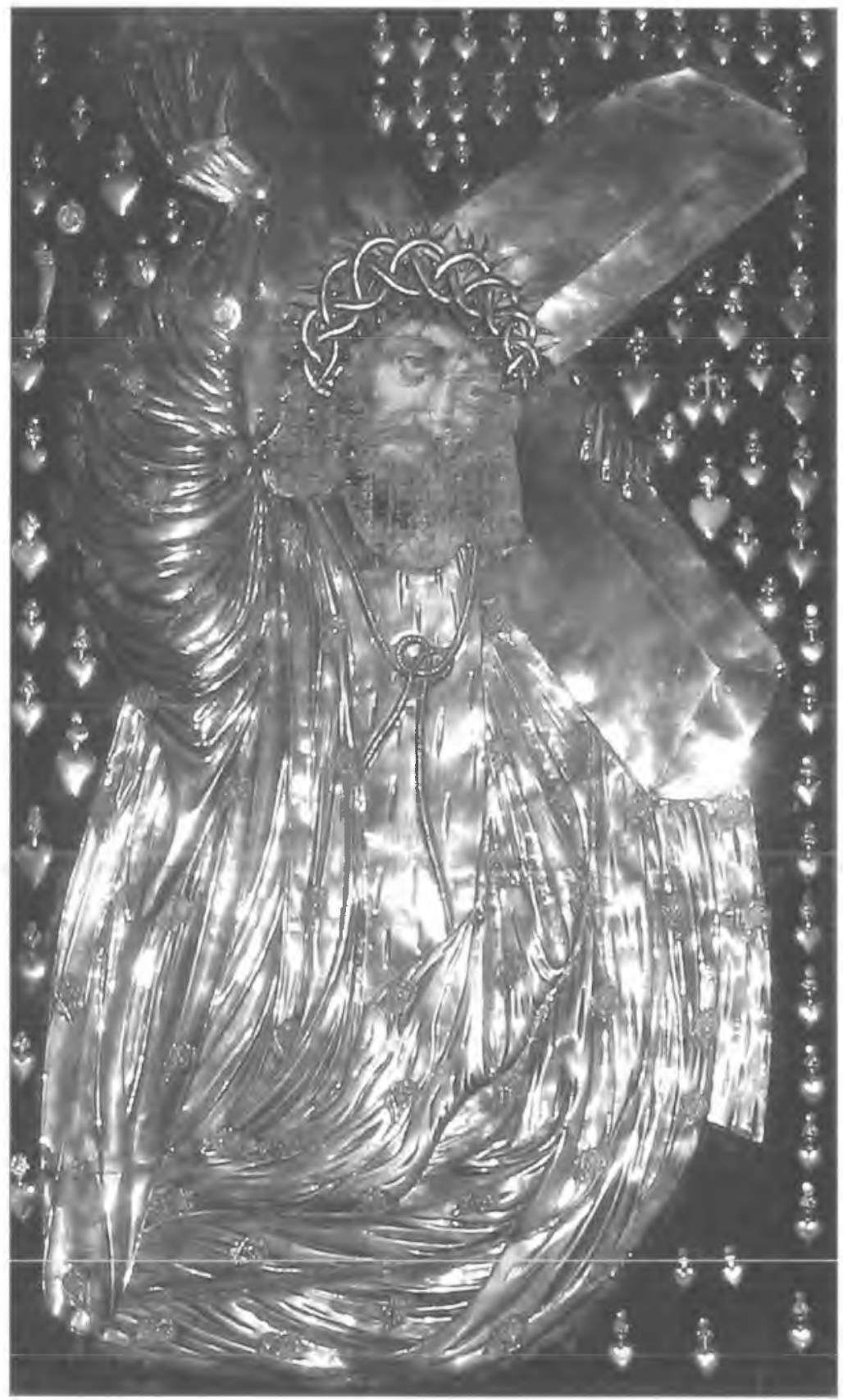

1. Chrystus niosący krzyż, obraz z kościoła karmelitów bosych we Lwowie, obecnie w kościele karmelitów trzewiczkowych $\mathrm{Na}$ Piasku w Krakowie (fot. J. Stec). 


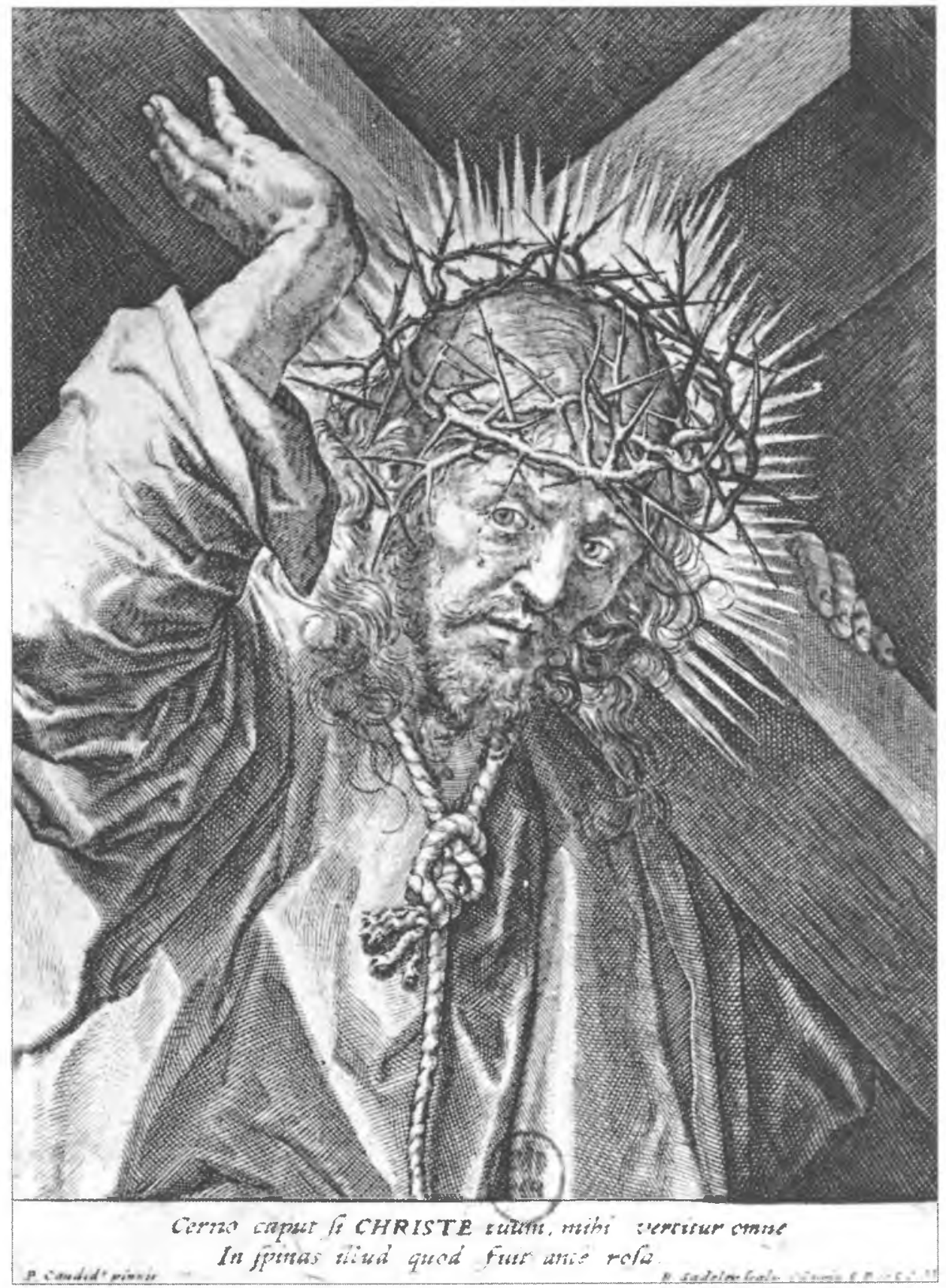

2. Chrystus niosący krzyż, miedzioryt Raphaela Sadelera I według Petera de Witte zw. Candidem (wg F. W. H. Hollstein, t. XXII). 